\title{
The practices and Understanding of Corporate Social Responsibility in Public sector of Pakistan: A CaseofPPL-Pakistan
}

\author{
Mushtaque Ali Jariko \\ PhD student-Department of Learning and Philosophy \\ Aalborg Universitet København / Aalborg University Copenhagen \\ AC Meyers Vænge 15,3.sal \\ 2450 København SV \\ Tania Mushtaque \\ PhD Student Department of Environmental, \\ Social and Spatial Change (ENSPAC) \\ Roskilde University, 1, 4000 Denmark. \\ Munir Ahmed Ahmadani \\ Assistant Professor-Govt-Commerce College \\ Hyderabad \\ Faiz Muhammad Shaikh \\ Assistant Professor-SZABAC-Dokri \\ Email:faizmuhammed_2000@yahoo.com \\ Syed Abdul Sattar Shah, \\ Asst. Prof. IBA University of Sindh, Jamshoro,
}

\begin{abstract}
The current research investigates the practices and understanding of Corporate Social Responsibility (CSR) in public sector of Pakistan. CSR is becoming very familiar in the field of business and is getting much popularity among scholars, academicians, practitioners, and communities. But, through this paper it is identified that practice and understanding of CSR in most of the developing nations including Pakistan is philanthropic and has not fully developed in accordance with international standards. Moreover, most of the companies believe that doing charitable activities is CSR. This, off course is not the CSR as it is being practiced and developed in the West. The discourse of CSR among the developing nations is still at infancy stage and has to develop in accordance with the International standards. Further, with the help of this paper CSR and its overall structure is presented in which some key theories of CSR are also presented. The purpose of presenting this is to make aware the public companies of Pakistan to think beyond the current philanthropic approach of CSR.We believe that by broadening the practice and understanding of CSR can help companies to better develop their image before the various stakeholders. Because, we believe that CSR oriented organizations are more efficient of attracting, motivating and retaining their internal stakeholders e.g. the employees and can have better image before the external stakeholders. Thus, we believe that more empirical research is needed and we encourage the future research be carried particularly in public sector because public sector plays vital role in solving the most of the societal problems. In this paper the extent literature on CSR is presented in which the broader perspective of CSR is discussed.
\end{abstract}

Key Words: Corporate Social Responsibility (CSR), PPL, Philanthropy, Public Sector, Pakistan

\section{Council for Innovative Research}

Peer Review Research Publishing System

\author{
Journal: International Journal Of Management \& Information Technology \\ Vol . 10, No 6 \\ editorsijmit@gmail.com \\ www.ijmit.com
}




\section{Introduction}

\section{CSR understanding and practice among developing nations}

Many scholars believe that understanding of CSR in most of the developing nations is philanthropic. See for example, (Jamali, Neville 2011, Dobers, Halme 2009, Debroux 2008, Chambers, Chapple et al. 2003, Jhatial, Cornelius et al. 2014a, Singh 2010). According to these authors CSR activities reflect philanthropic approach and most of the companies believe in charitable contribution. For example, Singh (2010) identified that this practice among Indian companies reflect the tradition of 'trusteeship' and this thought was originally given by Gandhi and also supported by some key corporate leaders. The findings from the Sings work reflect that CSR activities are aimed at contributing to society resulting in benefiting the firms. And the Sings work further suggests that much work is required to do with CSR and companies should strive to make 'social responsible investment. Likewise, (Jamali, Mirshak 2007) have identified that most of the companies in Lebanon are engaged in voluntarily CSR activities and their main motivation to do this is to fulfill public responsibility. Based on their data collected from eight large companies in Lebanon Jamali and Mirshak suggest that comprehensive 'CSR programs need to be formulated so that companies should think beyond the boundaries of fulfilling public responsibility'. Similarly,(Khan, Majid et al. 2013, Makki, Lodhi 2008)have also identified that the concept of corporate philanthropy among Pakistani companies is gaining importance. According to these authors Pakistani companies are engaged in philanthropic activities with main purpose to earn good name in the market. Further, these authors have identified that among Pakistani companies the philanthropic activities are medical help, scholarships, donations, and other charitable contributions.

Likewise, (Uddin, Hassan et al. 2008) have studied Bangladeshi companies and have compared three core elements of CSR including; economic, social, environmental, and ethical with the current practice of CSR in Bangladesh. According to these authors most of the local and multinational companies are engaged in developing the name of their own brand in the market; however some of the local companies have started mentioning their activities mainly associated with humanitarian actions. Similarly, (Paryani 2011) has argued that stakeholders have key positions in the field of CSR and he believes that in countries like Pakistan Stakeholders are required to be more focused, effective, and efficient towards good corporate governance and implementation of CSR.(Paryani 2011).

Another reason the developing nations strongly believe in giving back to the communities is the natural disasters which the companies working in such countries believe that giving back to the communities is the moral obligation upon them. For example, (Muller, Whiteman 2009) have identified after Tsunami, Kashmir Earth quake the companies around the world started supporting the affected areas. These authors have identified that the Asian firms were relatively lower than their counterpart in the donation to the major natural disasters According to Muller and Whiteman shareholders seem to be more dominant and local companies working there do not have social and environmental concerns in their business operations. Muller and Whiteman further suggest that the collaborative efforts between the regions can strengthen the network between firms and by doing so the humanitarian organization can be helped and supported. Likewise, (Blowfield, Frynas 2005) identified that CSR different approaches do not guarantee development and sustainability in marginalized and poor countries having severe problems of socio-economic, environmental, and cultural. Thus, Blowfield and Fryans suggest that a well-structured concept of CSR in relation to developing nations needs to be formulated so that such core issues need to be addressed in a proper way. The problems of low per capita income, human and social problems are not limit to poor countries; similar challenges are being faced by developed and developing nations (Visser, Matten et al. 2010). Viser et al suggest that In order to mitigate social and economic problems and how CSR could help communities and businesses across continents, a well-structured roadmap of CSR can help resolving such issues.

From the above literature it is obvious that the most of the public, private, and multinational companies in developing countries and in Pakistan use philanthropic approach to serve the community, which according to many researchers and scholars is the only part of CSR. For example (Carroll 1979, Carroll 1999, Carroll 1991, Davis 1960, Davis 1973, Wood 1991, Wood, Jones 1995) presented the concept of CSR in its totality and identified that CSR is beyond the philanthropic approach.

\section{Focus on Pakistani publicly owned companies and the role of public sector in CSR}

In this section we have attempted to rationalize the reason behind choosing the public companies of Pakistan and a brief literature on public sector role in CSR is also presented.

Pakistan being a developing nation in the Asia got its independence in 1947 from the colonial British rules. The purpose of this independence was to give a better future to the people of Pakistan. But, unfortunately major sectors including public sectors did not grow and develop. For example, (Waheed 2005, Abbasi 2011, Safdar 2012) have identified that Pakistan after independence came across with severe political, economic, social, and environmental problems. For example, Waheed (2005) the major problems faced by Pakistani are "poverty, ethnic violence, social and economic problems, instability within the Governments, Dictatorship". similarly, Abbasi(2011) mentioned that public sector in Pakistan has not been addressing the core issues faced by the nations on the other hand the sole responsibility of Public sector is to give services to their people. Likewise, Safdar (2102) based on his empirical work has identified that the public sector organizations in Pakistan are considered as one of the inefficient institutes of the country.

Public companies contribute more in the welfare and development program in any country as these companies represent public Institute and are equally accountable to public for their actions. The importance of public sector and their role has been reported by the number of researchers and scholars. See for example, (Jamali, Hallal et al. 2010, Safieddine, Jamali et al. 2009, Franco-Rodriguez, Morrissey et al. 1998, Fox, Ward et al. 2002). According to these authors public sectors 
can play very important role in satisfying the stakeholders and this can be done through increased financial performance and considering the larger interest of stakeholders. Further, (Angus-Leppan, Metcalf et al. 2010) have identified that leadership of respective countries can play the leading roles in initiating and implementing CSR activities. These authors believe that in this perspective the World Bank can play its pivotal role in enhancing the possibility of CSR implementation. Similarly, the world bank in its report mentions that "Public sector organizations have broad-based responsibilities of serving people, taking care of their interests, enable suitable environment for business, provide sound policies, information, assistance and it is equally imperative for the state to create, sustain and augment institutional structures befitting the myriad of minimal, intermediate and activist functions it performs to improve social equity and address market failure". Likewise, (Fox, Ward et al. 2002) have also identified that public sector companies have huge responsibilities and can better contribute in resolving the social and environmental problems.

Through literature and some past studies it is learnt that most of Public companies in developing nations particularly in Pakistan are engaged in philanthropic activities. Which according to many scholars do not qualify CSR in its entirety see for example, Bowen, Davis, and Carroll? These authors believe that CSR is beyond from philanthropic activities and it has other dimensions including economic, legal, ethical, social, philanthropic, and environmental. Even more recently, United Nations (UN) has issued certain guiding principles for the companies for CSR initiatives. For example, (Rasche 2009, Rasche, Kell 2010, Gilbert, Behnam 2013) have identified that with advent of globalization the firms have started realizing the importance of global compact and in various countries have started contributing in different societies. Likewise, (Kell 2003, Kell 2005, Williams 2007) have identified that UN global compact principles were designed to help in promoting the responsible and moral business on global level. Further, many authors believe that UN global compact can be materialized provided if the partnership between various actors is encouraged. See for example, (Newell, Frynas 2007a, Utting 2007, Wettstein 2012, Ruggie 2001, Voegtlin, Pless 2014).

On the basis of CSR practice found in developing nations and studying the current understanding and practice of CSR within Public sector companies of Pakistan.We conclude that CSR should be understood in its wider scope and other dimensions for example economic, legal, ethical, and philanthropic of it must also be addressed among the public companies.

\section{Genesis of Pakistani philanthropy.}

In this part of the paper we have tried to give a brief account of faith and philanthropy in Pakistan. Pakistan got independence in 1947 from the British rule which dominated the whole subcontinent more than 200 years. Pakistan was separated from India on the basis of two- nation theory in which the founder of Pakistan Muhammad Ali Jinnah believed that two nations having two different religions, culture, and traditions cannot live together. Pakistan appeared as Muslim nation in the world map and majority of the people living in Pakistan are Muslims. During colonial system the British government also encouraged the social welfare activities and during this period the British made provisions in various Institutions for voluntarily services including philanthropy. See for example, (Jaffrelot 2004, Rashid 1987, Emerson 1969, Qureshi, Seth et al. 1998) who have identified the causes of independence of Pakistan and have also highlighted the issues which emerged after the Independence.

The foundation of Pakistan was made on the basis of religious identity and this has been the dominating factor since independence. Pakistani nation has been very active in participating the social and welfare activities being carried by the national, multinational, and Non- Governmental organizations. For example, the existence of Edhi welfare Fiundation, ShoukatKhanum Memorial Cancer hospital , and many government and private companies such as;(Pakistan Petroleum Limited (PPL), Pakistan State Oil (PSO), Pakistan Air Line(PIA), ICI Pakistan Limited, Engro Chemical Pakistan Limited, Unilever Pakistan Limited, National Foods Pakistan Limited, Proctor and Gamble Pakistan). Many have given a tribute to Abdul SattarEdhi who while living a simple life has contributed a lot in the welfare programs of Pakistan. See for example, (Hashmi 2011, LEADER ) who have identified that a man who lives so simple life and has spent whole his life in charitable activities. Similarly, (Bhatti, Ashraf et al. 2014) have identified that Imran Khan the founder of ShaukatKhanum Memorial hospital has lead the hospital in providing a greater help to the needy and poor of the nation. Likewise, (Ghaffar, Zaidi et al. 2013) have identified that health sector has much been found in philanthropic activities.

Pakistan being an Islamic state believes in the Islamic principles and pillars therefor the companies working in Pakistan are one or other way fulfill the religious obligation as a part of ZAKKAT. For example, (Ullah, Jamali 2010, Williams, Zinkin 2010, Zinkin 2007, Bremer 2004) have identified that in most of the Muslim countries the companies feel obligations to give back to societies in various charitable forms. Likewise, (Bremer 2004, Dusuki 2008) have identified that in Muslim nations the Islamic perspective of CSR is viewed and practiced in the form of Zakat. According to these authors Zakat is treated obligatory on every Muslim depending on their income. Therefore, the history of philanthropy and engagement of companies in voluntarily activities can be seen from the religious perspective of Islam. Many believe that religion has historically been a major source of inspiration for many of these involved in welfare activities. For example, (Alterman, Hunter 2004) have argued that philanthropy in Muslim context has worked under Islamic tenets. Further, according to these authors "Philanthropy and charity are central tenets of Islam, and many Muslims regard charity as a form of worship. According to traditional conceptions of Islam, charity is one of the five pillars of the faith (along with prayer, belief in God and the Prophet Muhammad, fasting in Ramadan, and pilgrimage to Mecca" (p. 03). Likewise, (Jamali 2014) has identified that CSR in Middle East only Islamic philanthropic followed by Voluntarily CSR is practiced which she believes that it is far behind from the CSR theories. 


\section{The literature Review}

There appears growing interest of academics and professionals to study CSR in developing societies. Past studies and literature in developing nations reflect that CSR activities in developing nations are moreover restricted on charity and humanity grounds and have not been fully developed in accordance with international standards. Most of the developing countries including some Muslim states are engaged in charitable activities and their CSR activities are deeply rooted on humanitarian grounds. See for example, (Bremer 2004, Dusuki 2008, Jamali, Mirshak 2007, Karam, Jamali 2012, Jhatial, Cornelius et al. 2014b).

CSR in Pakistan is in the initial stage and most of the companies contribute in philanthropic activities focusing on donations, charity, community development, education(Ehsan, Kaleem 2012, Jhatial, Cornelius et al. 2014b, Khan, Majid et al. 2013, Makki, Lodhi 2008, Mushtaq 2013, Naeem, Welford 2009). These authors believe that CSR is not being fully addressed in accordance with global perspective and they also believe that the current practice and understanding needs to be revisited.

Most recently, Jhatial, Cornelius et al. (2014) through empirical data studied the practice of CSR in national and multinational companies of Pakistan and identified that most of the companies in order to earn good name are engaged in philanthropic CSR activities. Further, according to these authors companies are engaged in support of providing support to the local community particularly during the natural disasters for instances, floods and earthquakes. These authors believe that Pakistan public companies can play a crucial role in initiating CSR activities.

In recent decades the concept of Corporate Social Responsibility (CSR) has become important strategy for companies to survive and increasing body of academic scholarship has contributed knowledge on CSR which signifies its importance to academic and business world alike. Much literature is available on the basic concept and definitions of CSR. There are number of scholars who have given the basic structure on CSR. For example, (Bowen 1953, Bowen 2013) was the first person to introduce the responsibilities of businessmen.Bowen came with the thought that managers have social responsibilities and they should consider while making decisions. According to Bowen the decisions made by the managers not only affect the internal stakeholders of the companies but also affect the external stakeholders.

Likewise,(Davis 1960) also identified that business are liable for making responsible decisions. Davis believes that in business decisions the core issues related to the environment, social and ethical aspects should be given priority. Similarly, (Frederick 1960) argued that in CSR business has to think in broaderperspective. According to Frederic business resources should be utilized for the betterment of societies. (McGuire 1963) also argued that business should not be established for the profit purposes. According to him business should think beyond economic and legal obligation and should contribute for the betterment of societies. Later,(Carroll 1979) came with a good concept of CSR upon which many scholars and researchers have got impression for their respective research project. Carroll floated a definition of CSR in which according to him CSR is: "The social responsibility of business encompasses the economic, legal, ethical and discretionary expectations that society has of organizations at a given point in time" (Carroll 1979, p. 500).

Eventually, much development in the field of CSR arose and the relationship between business and societies started became more visible. Thus, the concept of stakeholder's perspective of CSR became the debate among the business communities. For example, (Freeman 1999, Freeman 1983, Steurer, Langer et al. 2005, Frooman 1999, Clarkson 1995) have identified that CSR is all about meeting the expectations of key stakeholders. The growing importance of stakeholder's engagement also started debated on the various business platforms. See for example, (World Business Council for Sustainable Development 1999, Commission of the European Communities 2001).

More specifically, UN global compact ten guiding principles have also been used by number of firms and have been benefited. For example, (Meyer, Stefanova 2001, Williams 2014) have identified that the UN compact principles were mainly initiated with the purpose to help in promoting responsible business practices around the world. Further, according to these authors most of the US firms do follow the guiding principles and are engaged in socially responsible business. Likewise, (Newell, Frynas 2007b) have identified that companies can do much in initiating their socially responsible business activities. For instances, these authors believe that in the areas such as environmental protection, employees and human rights the companies can do much more to be socially responsible. Eventually, with the advent of globalization the companies are becoming more accountable in the eyes of various stakeholders and many authors have identified that with the increasing number of Multinational companies the social problems are also becoming the agenda of companies to resolve. See for example, (Ruggie 2001, Ruggie 2007, Gilbert, Behnam 2013).

From the above literature it can be seen that CSR practice and understanding in Pakistan is very limited and is not fully developed in accordance with theories of CSR as proposed by Carroll. Further, the activities of CSR in Pakistan indicate that only philanthropic approach is dominating factor. Therefore, it is concluded that CSR in public sector of Pakistan is not practiced in its entirety. We therefore, suggest that a comprehensive CSR approach needs to be initiated and implemented within the public sector of Pakistan so that they can render better services to the society. In short, we propose that Carroll's theory of CSR and other dimensions of CSR as proposed by (Bowen 1953, Davis 1960, Davis 1973, Frederick 1960, Freeman 1983).

We believe that Carroll's four- part definition construct comprising economic, legal, ethical, and philanthropic domains of CSR can be the helping tool for the companies working in Pakistan to initiate and implement CSR. 


\section{Methodology}

Data were collected by using the literature review method. And, some key definitions and theories of CSR are also referred.

\section{Discussions}

The aim of this paper was to present the current understanding of CSR among Pakistani companies. We took the example ofPakistan Petroleum Limited (PPL). PPL has been a frontline player in the energy sector since the mid-1950s. As a major supplier of natural gas, PPL today contributes over 20 percent of the country's total natural gas supplies besides producing crude oil, Natural Gas Liquid and Liquefied Petroleum Gas. PPL operates six producing fields across the country at Sui (Pakistan's largest gas field), Adhi, Kandhkot, Chachar, Mazarani and Hala and holds working interest in fifteen partner-operated producing fields, including Qadirpur the country's second largest gas field.As a major stakeholder in securing a safe energy future for the country, PPL pursues an aggressive exploration agenda aimed at enhancing hydrocarbon recovery and replenish reserves. Over the years, PPL has developed a reliable foundation and infrastructure for providing clean and safe energy through sustainable exploitation of indigenous natural resources while adhering to best practices of corporate governance and employee health and safety and constraining the ecological footprint of its operations. PPL has played a significant role as a responsible corporate citizen since the inception of its commercial activities in Sui by establishing the Sui Model School in 1957 for children of workers and local communities. In 2001, the PPL Welfare Trust was founded to provide geographical and thematic diversity to the company's CSR program, which currently includes education, health, infrastructure development and socio-economic uplift of disadvantaged communities living in and around its operating areas as well as other parts of the country.

Having said, that this large company believes in giving back to the society in various forms of charitable activities and is engaged in sustainable businesses. We believe that if this company would like to flourish in the eyes of international stakeholders then adopting and using Carroll theory of CSR in their current practice might open other possibilities for the companies to grow. In addition to that using Carroll's framework of CSR in their current practice might also help the company to design a mechanism which addresses all the major dimensions of CSR including economic, legal, ethical, and philanthropic. In short, we believe that having partnership with international community can also be an inspirational source for the company to learn more about the CSR activities. Doing so, we believe that PPL can be a sample for other companies working in Pakistan and thus the overall growing importance of CSR can emerge and can have positive consequences.

\section{Conclusion}

CSR among the developing nations is still at infancy stage and has to develop in accordance with the International standards. Further, the practice and understanding of CSR within the Pakistani public companies is inclined towards philanthropic approach. It was also identified that Pakistan public sector has gone with number of political, social, economic, and environmental problems. We believe that a strategic policy at the state level is needed to foster the CSR culture so that the problems being faced by the societies can be resolved. We believe that by broadening the practice and understanding of CSR can help companies to better develop their image before the various stakeholders. Because, we believe that CSR oriented organizations are more efficient of attracting, motivating and retaining their internal stakeholders e.g. the employees and can have better image before the external stakeholders.

In the end we suggest that current practice and understanding of CSR needs to changed and CSR should be implemented in accordance with Carroll's theory of CSR. Moreover, the partnership between various actors can also be an effective way of inculcating CSR culture within the public companies of Pakistan. UN global compact principles can also be other way of addressing the CSR in its true spirit. Further, we encourage that empirical research in the field of CSR should be carried particularly in public sector because public sector plays vital role in solving the most of the societal problems.

\section{References}

1. ABBASI, A., 2011. Public Sector Governance in Pakistan: Board of Investment (BOI). International journal of politics and good governance, 2(2),

2. ALTERMAN, J.B. and HUNTER, S., 2004. The idea of philanthropy in Muslim contexts. Washington, DC: CSIS,

3. ANGUS-LEPPAN, T., METCALF, L. and BENN, S., 2010. Leadership styles and CSR practice: An examination of sensemaking, institutional drivers and CSR leadership. Journal of Business Ethics, 93(2), pp. 189-213.

4. BHATTI, A., ASHRAF, J. and AKHTAR, M.F., 2014. Shaukat Khanum Memorial Cancer Hospital and Research Centre Endowment Fund. Asian Journal of Management Cases, 11(2), pp. 71-87.

5. BLOWFIELD, M. and FRYNAS, J.G., 2005. Editorial Setting new agendas: critical perspectives on Corporate Social Responsibility in the developing world. International Affairs, 81(3), pp. 499-513.

6. BOWEN, H.R., 2013. Social responsibilities of the businessman.University of lowa Press.

7. BOWEN, H.R., 1953. Social responsibilities of the businessman.Harper \& Brothers. 


\section{ISSN 2278-5612}

8. BREMER, J., 2004. Islamic philanthropy: Reviving traditional forms for building social justice. Washington DC, University of North Carolina, Chapel Hill, , pp. 28-29.

9. CARROLL, A.B., 1979. A three-dimensional conceptual model of corporate performance.Academy of management review, 4(4), pp. 497-505.

10. CHAMBERS, E., CHAPPLE, W., MOON, J. and SULLIVAN, M., 2003. CSR in Asia: A seven country study of CSR website reporting.

11. CLARKSON, M.E., 1995. A stakeholder framework for analyzing and evaluating corporate social performance.Academy of management review, 20(1), pp. 92-117.

12. COMMISSION OF THE EUROPEAN COMMUNITIES, 2001.GREEN PAPER: Promoting a European framework for corporate social responsibility. Commission of the European Communities.

13. DAVIS, K., 1973. The case for and against business assumption of social responsibilities. Academy of Management journal, 16(2), pp. 312-322.

14. DAVIS, K., 1960. Can business afford to ignore social responsibilities? California management review, 2(3),.

15. DEBROUX, P., 2008. Corporate Social Responsibility and Sustainable Development in Asia: a Growing Awareness. Soka Keiei Ronshu, 32(1), pp. 2.

16. DOBERS, P. and HALME, M., 2009.Corporate social responsibility and developing countries. Corporate Social Responsibility and Environmental Management, 16(5), pp. 237-249.

17. DUSUKI, A.W., 2008. What does Islam say about corporate social responsibility? review of Islamic economics, 12(1), pp. 5-28.

18. EHSAN, S. and KALEEM, A., 2012.An Empirical investigation of the relationship between Corporate Social Responsibility and Financial Performance (Evidence from Manufacturing Sector of Pakistan). Journal of Basic and Applied Scientific Research, 2(3), pp. 2909-2922.

19. EMERSON, R., 1969. Colonialism. Journal of Contemporary History, , pp. 3-16.

20. FOX, T., WARD, H. and HOWARD, B., 2002. Public sector roles in strengthening corporate social responsibility: a baseline study. World Bank Washington, DC.

21. FRANCO-RODRIGUEZ, S., MORRISSEY, O. and MCGILLIVRAY, M., 1998. Aid and the public sector in Pakistan: evidence with endogenous aid. World Development, 26(7), pp. 1241-1250.

22. FREDERICK, W.C., 1960. The growing concern over business responsibility. California management review, 2(4), pp. 54-61.

23. FREEMAN, R.E., 1999. Divergent stakeholder theory.Academy of management review, 24(2), pp. 233-236.

24. FREEMAN, R.E., 1983. Strategic management: A stakeholder approach. Advances in strategic management, 1(1), pp. 31-60.

25. FROOMAN, J., 1999. Stakeholder influence strategies. Academy of management review, 24(2), pp. 191-205.

26. GHAFFAR, A., ZAIDI, S., QURESHI, H. and HAFEEZ, A., 2013.Philanthropic funding for health in Pakistan. Environment, 6, pp. 4.

27. GILBERT, D.U. and BEHNAM, M., 2013. Trust and the United Nations Global Compact A Network Theory Perspective. Business \& Society, 52(1), pp. 135-169.

28. HASHMI, W.H., 2011. Abdul Sattar Edhi: A Tribute. Pakistaniaat: A Journal of Pakistan Studies, 3(2), pp. 116123.

29. JAFFRELOT, C., 2004.A History of Pakistan and its Origins.Anthem Press.

30. JAMALI, D., 2014. Overview of corporate social responsibility in the middle east. The World Financial Review, , pp. 71-72.

31. JAMALI, D., HALLAL, M. and ABDALLAH, H., 2010. Corporate governance and corporate social responsibility: evidence from the healthcare sector. Corporate governance, 10(5), pp. 590-602.

32. JAMALI, D. and MIRSHAK, R., 2007. Corporate social responsibility (CSR): theory and practice in a developing country context. Journal of Business Ethics, 72(3), pp. 243-262.

33. JAMALI, D. and NEVILLE, B., 2011. Convergence versus divergence of CSR in developing countries: An embedded multi-layered institutional lens. Journal of Business Ethics, 102(4), pp. 599-621.

34. JHATIAL, A.A., CORNELIUS, N. and WALLACE, J., 2014a. 6 Corporate social responsibility in Pakistan. Corporate Social Responsibility and Local Community in Asia, , pp. 111. 


\section{ISSN 2278-5612}

35. JHATIAL, A.A., CORNELIUS, N. and WALLACE, J., 2014b. 6 Corporate social responsibility in Pakistan. Corporate Social Responsibility and Local Community in Asia, , pp. 111.

36. KARAM, C.M. and JAMALI, D., 2012. Gendering CSR in the Arab Middle East. Business Ethics Quarterly, 23(1), pp. 31-68.

37. KELL, G., 2005. The global compact selected experiences and reflections. Journal of Business Ethics, 59(1-2), pp. 69-79.

38. KELL, G., 2003. The Global Compact.Journal of Corporate Citizenship, 2003(11), pp. 35-49.

39. KHAN, M., MAJID, A., YASIR, M. and ARSHAD, M., 2013. Corporate Social Responsibility and Corporate Reputation: A Case of Cement Industry in Pakistan.

40. LEADER, S., DR. ABDUL SATTAR EDHI.Leaders of Pakistan, , pp. 2.

41. MAKKI, M.A.M. and LODHI, S.A., 2008.Determinants of corporate philanthropy in Pakistan.Pakistan Journal of Commerce and Social Sciences, 1, pp. 17-24.

42. MCGUIRE, J.W., 1963. Business and society.McGraw-Hill New York.

43. MEYER, W.H. and STEFANOVA, B., 2001. Human Rights, the UN Global Compact, and Global Governance. Cornell Int'I LJ, 34, pp. 501.

44. MULLER, A. and WHITEMAN, G., 2009. Exploring the geography of corporate philanthropic disaster response: A study of Fortune Global 500 firms. Journal of Business Ethics, 84(4), pp. 589-603.

45. MUSHTAQ, N., 2013. PARAMOUNT ROLE OF CORPORATE SOCIAL RESPONSIBILITY IN RETAINING EMPLOYEES AND CORPORATE REPUTATION: AN EXTRACT FROM PAKISTAN'S BANKING SECTOR. Journal of Business and Finance, 1(3), pp. 126-138.

46. NAEEM, M.A. and WELFORD, R., 2009. A comparative study of corporate social responsibility in Bangladesh and Pakistan.Corporate Social Responsibility and Environmental Management, 16(2), pp. 108-122.

47. NEWELL, P. and FRYNAS, J.G., 2007a.Beyond CSR? Business, poverty and social justice: an introduction. Third World Quarterly, 28(4), pp. 669-681.

48. NEWELL, P. and FRYNAS, J.G., 2007b.Beyond CSR? Business, poverty and social justice: an introduction. Third World Quarterly, 28(4), pp. 669-681.

49. PARYANI, M.A., 2011. Corporate Social Responsibility, the Role of Stakeholders and Sustainable Development "A Case Study of Pakistan". Cell, 92, pp. 333-3755278.

50. QURESHI, R., SETH, H.N., UDDIN, S. and AHMED, M., 1998. History of Pakistan.

51. RASCHE, A., 2009. "A Necessary Supplement" What the United Nations Global Compact Is and Is Not. Business \& Society, 48(4), pp. 511-537.

52. RASCHE, A. and KELL, G., 2010. The United Nations global compact: Achievements, trends and challenges. Cambridge University Press.

53. RASHID, S.A., 1987. A Short History of Pakistan. General Editor IH Qureshi (University of Karachi, 1984), , pp. 602-607.

54. RUGGIE, J.G., 2007. Business and human rights: the evolving international agenda. American Journal of International Law, , pp. 819-840.

55. RUGGIE, J.G., 2001. global_governance. net: The Global Compact as learning network. Global Governance, , pp. 371-378.

56. SAFDAR, R., 2012. Performance Measurement And Civil Services Reforms In Pakistan: A Study Of Public Sector Organizations. Far East Journal of Psychology and Business, 6(5), pp. 56-68.

57. SAFIEDDINE, A., JAMALI, D. and NOUREDDINE, S., 2009. Corporate governance and intellectual capital: evidence from an academic institution. Corporate Governance, 9(2), pp. 146-157.

58. SINGH, S., 2010. Philanthropy to Corporate Social Responsibility: An Indian Perspective. Review of International Comparative Management, 11(5), pp. 990-1000.

59. STEURER, R., LANGER, M.E., KONRAD, A. and MARTINUZZI, A., 2005. Corporations, stakeholders and sustainable development I: A theoretical exploration of business-society relations. Journal of Business Ethics, 61(3), pp. 263-281.

60. UDDIN, M.B., HASSAN, M.R. and TARIQUE, K.M., 2008. Three dimensional aspects of corporate social responsibility.

61. ULLAH, S. and JAMALI, D., 2010. Institutional investors and corporate social responsibility: the role of Islamic financial institutions. International review of business research papers, 6(1), pp. 619-630. 


\section{ISSN 2278-5612}

62. UTTING, P., 2007.CSR and equality. Third World Quarterly, 28(4), pp. 697-712.

63. VOEGTLIN, C. and PLESS, N.M., 2014. Global Governance: CSR and the Role of the UN Global Compact. Journal of Business Ethics, , pp. 1-13.

64. WAHEED, A., 2005.SECURITIES \& EXCHANGE COMMISSION OF PAKISTAN And UNITED NATIONS DEVELOPMENT PROGRAM.

65. WETTSTEIN, F., 2012. CSR and the Debate on Business and Human Rights. Business Ethics Quarterly, 22(4), pp. 739-770.

66. WILLIAMS, G. and ZINKIN, J., 2010. Islam and CSR: A study of the compatibility between the tenets of Islam and the UN Global Compact. Journal of Business Ethics, 91(4), pp. 519-533.

67. WILLIAMS, O.F., 2014. The United Nations Global Compact: What Did It Promise? Journal of Business Ethics, 122(2), pp. 241-251.

68. WILLIAMS, O.F., 2007. The UN Global Compact: The challenge and the promise. Corporate Ethics and Corporate Governance. Springer, pp. 287-308.

69. WORLD BUSINESS COUNCIL FOR SUSTAINABLE DEVELOPMENT, 1999.Corporate social responsibility: Meeting changing expectations. World Business Council for Sustainable Development.

70. ZINKIN, J., 2007. Islam and CSR: a study of the compatibility between the tenets of Islam, the UN Global Compact and the development of social, human and natural capital. Corporate social responsibility and environmental management, 14(4), pp. 206-218. 